\title{
Stem cell-based treatments against stroke: observations from human proof-of-concept studies and considerations regarding clinical applicability
}

\author{
Thorsten R. Doeppner* and Dirk M. Hermann \\ Department of Neurology, University of Duisburg-Essen Medical School, Essen, Germany
}

\section{Edited by:}

Lawrence Rajendran, University

Zurich, Switzerland

Reviewed by:

Alino Martinez-Marcos, Universidad de Castilla, Spain

Robert Weissert, University of

Regensburg, Germany

*Correspondence:

Thorsten R. Doeppner, Department

of Neurology, University of

Duisburg-Essen Medical School,

Hufelandstr. 55, 45147 Essen,

Germany

e-mail: thorsten.doeppner@

uk-essen.de
Ischemic stroke remains a heavy burden for industrialized countries. The only causal therapy is the recanalization of occluded vessels via thrombolysis, which due to a narrow time window still can be offered only to a minority of patients. Since the majority of patients continues to exhibit neurological deficits even following successful thrombolysis, restorative therapies are urgently needed that promote brain remodeling and repair once stroke injury has occurred. Due to their unique properties of action, stem cell-based strategies gained increasing interest during recent years. Using various stroke models in both rodents and primates, the transplantation of stem cells, namely of bone marrow derived mesenchymal stem cells (MSCs) or neural progenitor cells (NPCs), has been shown to promote neurological recovery most likely via indirect bystander actions. In view of promising observations, clinical proof-of-concept studies are currently under way, in which effects of stem and precursor cells are evaluated in human stroke patients. In this review we summarize already published studies, which due to the broad experience in other medical contexts mostly employed bone marrow-derived MSCs by means of intravenous transplantation. With the overall number of clinical trials limited in number, only a fraction of these studies used non-treated control groups, and only single studies were adequately blinded. Despite these limitations, first promising results justify the need for more elaborate clinical trials in order to make stem cell transplantation a success for stroke treatment in the future.

Keywords: stem cells, stroke, mesenchymal stem cells, neural progenitor cells, trials

\section{STEM AND PROGENITOR CELLS IN EXPERIMENTAL STROKE MODELS}

In defined areas of the adult brain such as the subgranular zone of the dentate gyrus and the subventricular zone (SVZ) of the lateral ventricles, endogenous neurogenesis persists during adulthood (Alvarez-Buylla and Garcia-Verdugo, 2002; Taupin and Gage, 2002; Silva-Vargas et al., 2013; Braun and Jessberger, 2014; Jessberger and Gage, 2014; Sawada et al., 2014). These neurogenic niches comprise astrocyte like neural stem and progenitor cells (NPC) that give rise to neurons under physiologic conditions (Doetsch et al., 1997, 1999). In rodent and primate stroke models, cerebral ischemia stimulates endogenous neurogenesis, and NPCs migrate from the SVZ towards the site of injury where they proliferate and differentiate into neurons (Liu et al., 1998; Arvidsson et al., 2002; Tonchev et al., 2003; Yamashita et al., 2006). Unfortunately, both differentiation and survival rates of endogenous NPCs are low (Parent, 2003; Haas et al., 2005; Doeppner et al., 2009). For this reason, the functional contribution of endogenous neurogenesis to post-ischemic neurological recovery remains a matter of debate.
In view of their restorative properties, efforts have been made to promote neurological recovery by transplantation of stem or progenitor cells in ischemic stroke. Although embryonic stem cells have the capacity to give rise to all cell lineages, their therapeutic potential is limited due to teratoma formation and ethical concerns (Blum and Benvenisty, 2008, 2009). Consequently, a wide variety of adult stem and progenitor cells from different species and various tissue sources have been used for therapeutic purposes, which were transplanted either locally or systemically in experimental models of focal cerebral ischemia (Bacigaluppi et al., 2008, 2009; Schwarting et al., 2008; Bliss et al., 2010; Zheng et al., 2010; Banerjee et al., 2012; Doeppner et al., 2012; Leong et al., 2012). Although grafted cells are not thought to be integrated into residing neural networks, they do promote neurological recovery via paracrine (indirect) mechanisms that involve the stimulation of endogenous angioneurogenesis and neural plasticity, stabilization of the blood brain barrier as well as modulation of peripheral and central immune responses (Doeppner et al., 2012; Hermann and Chopp, 2012; Mora-Lee et al., 2012; Zhang and Chopp, 2013). Despite the fact that questions related to the optimal cell type, the most adequate cell delivery 
Table 1 | Clinical trials using stem cells or progenitor cells against stroke

\begin{tabular}{|c|c|c|c|}
\hline Authors & Year & Cell type & Key findings \\
\hline Bang et al. & 2005 & MSCs & $\begin{array}{l}\text { Cells were intravenously grafted twice within } 9 \text { weeks post-stroke. Better } \\
\text { outcome in Barthel index after } 1 \text { year, but no effect on NIHSS and MRI scan. }\end{array}$ \\
\hline Lee et al. & 2010 & MSCs & $\begin{array}{l}\text { Intravenous cell grafting twice post-stroke with observation period of } 5 \text { years. } \\
\text { Better outcome in mRS. }\end{array}$ \\
\hline Bhasin et al. & 2011 & MSCs & $\begin{array}{l}\text { Autologous intravenous MSC transplantation. Within } 24 \text { weeks, no signifi- } \\
\text { cant side effects observed plus putative increased neural plasticity. }\end{array}$ \\
\hline Bhasin et al. & 2013 & MSCs & $\begin{array}{l}\text { Intravenous MSC transplantation followed by observation period of } 24 \\
\text { weeks. Statistically improved modified Barthel Index and increased neural } \\
\text { plasticity after stem cell treatment. No side effects. }\end{array}$ \\
\hline Honmou et al. & 2011 & MSCs & $\begin{array}{l}\text { Intravenous cell transplantation showed no side effects during } 1 \text { year of } \\
\text { follow-up. Reduction of lesion volume by }>20 \% \text { after } 1 \text { week. }\end{array}$ \\
\hline Savitz et al. & 2011 & MSCs & $\begin{array}{l}\text { Intravenous transplantation of MSCs within } 72 \text { h post-stroke plus observa- } \\
\text { tion period of } 6 \text { months. No study-related side effects. Median NIHSS } 13 \\
\text { before cell grafting and } 3 \text { after } 6 \text { months. }\end{array}$ \\
\hline Barbosa da Fonseca et al. & 2010 & MSCs & $\begin{array}{l}\text { Intraarterial delivery of } 99 \mathrm{mTc} \text {-labeled MSCs. Significantly reduced intracere- } \\
\text { bral numbers of grafted cells after } 24 \mathrm{~h} \text {. No significant side effects for as long } \\
\text { as } 120 \text { days. }\end{array}$ \\
\hline Moniche et al. & 2012 & MSCs & $\begin{array}{l}\text { Intraarterial infusion of MSCs between 5-9 days post-stroke. After } 6 \text { months, } \\
\text { no side effects but also no improved functional outcome. }\end{array}$ \\
\hline Suárez-Monteagudo et al. & 2009 & MSCs & $\begin{array}{l}\text { Stereotactic transplantation of cells into } 5 \text { patients. Authors claim discrete } \\
\text { functional improvement after } 1 \text { year. }\end{array}$ \\
\hline Kondziolka et al. & 2000 & Cultured neuronal cells & $\begin{array}{l}\text { Stereotactic delivery of cells with observation period of } 18 \text { months. Some } \\
\text { functional improvement. No relevant safety issues. }\end{array}$ \\
\hline Kondziolka et al. & 2005 & Cultured neuronal cells & $\begin{array}{l}\text { Stereotactic cell delivery with maximal observation period of } 24 \text { months. } \\
\text { Some functional improvement, but primary outcome was not met. No } \\
\text { significant adverse events. }\end{array}$ \\
\hline Savitz et al. & 2005 & $\begin{array}{l}\text { Fetal lateral eminescence } \\
\text { (=neural) cells }\end{array}$ & $\begin{array}{l}\text { Cells were pre-treated with anti-MHC I antibody and intracerebrally delivered. } \\
\text { Study was stopped after } 5 \text { patients. Significant side effects. }\end{array}$ \\
\hline Rabinovich et al. & 2005 & $\begin{array}{l}\text { Cell suspension from } \\
\text { immature nervous and } \\
\text { hemopoietic tissue }\end{array}$ & $\begin{array}{l}\text { Intrathecal cell delivery in } 10 \text { patients. No significant side effects during } 6 \\
\text { months of observation. }\end{array}$ \\
\hline
\end{tabular}

The table describes the studies quoted in the main text with special regard to key findings, the cell type used and the year of publication. MRI: magnetic resonance imaging, mRS: modified Rankin Scale, MSCs: mesenchymal stem cells, NIHSS: National Institutes of Health Stroke Scale.

time point and the route of cell delivery are still vividly discussed, clinical trials have been on the way with some of them holding promising results. Due to the broad experience with these cells in other clinical contexts, the most widely used cell source in clinical stroke studies are mesenchymal stem cells (MSCs), which are mostly derived from bone marrow. Besides, NPCs are also used in stroke patients. The following paragraphs provide an overview on major clinical trials (Table 1), which due to the existence of multiple investigator-driven smaller trials by no means claims to be exhaustive.

\section{CLINICAL STROKE TRIALS USING STEM OR PROGENITOR CELLS MESENCHYMAL STEM CELL SOURCES}

MSCs have been successfully used under various experimental paradigms (Chen et al., 2001, 2003; Li et al., 2002; Kurozumi et al., 2005; Ukai et al., 2007; Onda et al., 2008; Yoo et al.,
2008; Kranz et al., 2010; Sheikh et al., 2011). Due to the long-lasting experience with MSC transplantation in other clinical contexts, namely in malignancies of the blood, MSCs have evolved as the preferred candidate for clinical transplantation studies. Characteristics of MSCs include adherence on plastic surfaces, expression of CD markers such as CD105, CD73 and CD90 as well as differentiation into fat, bone and cartilage tissue (Dominici et al., 2006). MSCs can be easily obtained from various tissue sources including bone marrow and adipose tissue (Bliss et al., 2007; Doeppner and Hermann, 2010). They can also be easily expanded in vitro and are regarded to be immunologically inert, which reduces the risk of rejection of grafted cells in allogeneic transplantation settings (Aggarwal and Pittenger, 2005; Beyth et al., 2005). Although MSCs can be induced to differentiate into neural tissue in vitro (Pittenger et al., 1999), their potential for neural differentiation is low. Nevertheless, transplantation of MSCs improves neurological outcome 
in experimental stroke models, which is attributed to paracrine effects of grafted cells (Caplan, 2009). As such, promising preclinical data lead to clinical studies using MSCs or bone marrowderived mononuclear progenitor cells (subsequently subsumed together as MSCs), the most relevant of which are presented in the next paragraph.

\section{CLINICAL PROOF-OF-CONCEPT STUDIES USING MESENCHYMAL STEM CELL TRANSPLANTATION}

In one of the very first randomized controlled phase I/II clinical trials, Bang et al. (2005) intravenously transplanted autologous MSCs twice within 9 weeks after stroke onset. During the observation period of 1 year, patients receiving MSCs showed better improvement of the Barthel Index than control patients, whereas National Institutes of Health Stroke Scale (NIHSS) score and brain injury assessed by magnetic resonance imaging (MRI) did not differ between groups. Patient numbers in this trial were low (5 MSC transplanted and 25 control patients), thus possibly explaining the lack of significant results in the latter readouts. Taking this lack of statistical power and concerns regarding the safety of fetal calf serum (Spees et al., 2004) that was used for ex vivo MSC expansion into account, the same study group performed an additional open-label and observerblinded clinical trial on patients suffering from severe strokes using an observation period of 5 years (Lee et al., 2010). As in their earlier study, MSCs were intravenously transplanted twice in a total of 16 patients, whereas controls received no injection. Although 4 patients from the MSC group died during the observation period, no significant side effects or comorbidities attributed to the transplantation itself were observed. Importantly, the modified Rankin Scale (mRS) score was significantly improved in patients receiving MSCs within the observation period. This improvement was associated with increased levels of stromal cell-derived factor-1 that is upregulated upon stroke in rodents and thought to be involved in MSC homing (Shen et al., 2007). Although Lee et al. (2010) significantly extended the observation period to 5 years, more definite conclusions about the efficacy of MSCs cannot be drawn from this study, which lacked randomization and true blinding. Interestingly however, beneficial effects related to MSC treatment seemed to correlate with the involvement of the SVZ into the stroke. Thus, MSC transplantation was more effective when the SVZ was not part of the evolving stroke lesion, suggesting an indirect action of MSCs that promote endogenous neuroregeneration. According to a recent MRI study, the SVZ is located in close proximity to stroke lesions in a large percentage of stroke patients. In a prospective cohort of 108 included patients with first-ever stroke, the distance from the nearest margin of the infarct to the SVZ was $\leq 2 \mathrm{~mm}$ in half of all patients exhibiting visible diffusion weighted image (DWI) lesions (Delavaran et al., 2013). Thus, the relationship between stroke lesion and SVZ may represent a hitherto under-recognized factor influencing responses to neurorestorative therapies (Lee et al., 2010).

In the meantime, further clinical trials provided evidence that intravenous MSC transplantation is safe and feasible in humans (Bhasin et al., 2011, 2013; Honmou et al., 2011; Savitz et al., 2011). However, scientific conclusions from these trials are hampered due to the heterogeneous study design, the different timing of cell delivery and considerable differences in size of study groups. As a matter of fact, only two of the aforementioned studies included non-treated control groups (Bhasin et al., 2011; Savitz et al., 2011). Nevertheless, these studies were not randomized or blinded, and beneficial effects due to MSC transplantation as described by Bhasin et al. therefore need further evaluation.

Since the homing of MSCs and other stem cells into the brain is limited after intravenous transplantation, a Brazilian group performed intraarterial infusions of ${ }^{99 m}$ Tc-labeled MSCs in six stroke patients with the aim of increasing the amount of grafted cells within the brain (Barbosa da Fonseca et al., 2010). Although significant cell homing was observed as early as $2 \mathrm{~h}$ post-stroke within the ischemic hemisphere, the latter was greatly diminished $24 \mathrm{~h}$ post-stroke. Within an observation period of 120 days, no significant side effects related to cell grafting were observed. Similar findings were reported by Battistella et al. (2011) for an observation period of 180 days after intraarterial MSC infusion during the chronic phase of the stroke. Noteworthy, conclusions from the aforementioned studies are limited by low patient numbers and a lack of appropriate blinding. Since MSCs are known to home into peripheral organs such as the lungs, questions remain about the safety of required interventional procedures, particularly in more severely affected patients suffering from serious comorbidities. Patient safety will have to be taken into account carefully in future treatment studies after a recent study did not observe a beneficial effect of intraarterial MSC transplantation in patients suffering from stroke (Moniche et al., 2012). In animal studies, intraarterial MSC delivery was not superior to intravenous delivery (Yang et al., 2013).

In an even smaller clinical study, Suarez-Monteagudo et al. successfully transplanted autologous MSCs stereotactically into the brain of five stroke patients, followed by an observation period of 1 year (Suárez-Monteagudo et al., 2009). Although the authors claimed a discrete functional improvement over time, a scientific evaluation of this observation is certainly misplaced due to the low patient number and the study trial itself with no adequate control group. A sample of five patients is even far too low to draw conclusions about therapeutic safety. Reports of neurological improvement in small patient cohorts are hampered by the fact that complication rates may not be adequately determined. The MSC delivery into the brain parenchyma should, if at all, be considered with great caution.

At present, further studies that analyze both safety and feasibility of MSCs in stroke patients are on the way. The U.S. National Institutes of Health ${ }^{1}$ currently list 10 clinical trials ranging from phases I to III upon the keywords "mesenchymal stem cells" and "stroke". The majority of these studies use intravenous cell delivery with primary outcome measurements of either safety or functional neurological improvement. However, the recruitment status of these studies remains heterogeneous with some trials having not yet recruited at all.

\footnotetext{
${ }^{1}$ www.clinicaltrials.gov
} 


\section{CRITICAL CONSIDERATIONS REGARDING MESENCHYMAL STEM CELL TRANSPLANTATION IN HUMANS}

Although clinical follow-up studies with observation periods of one or 5 years did not show significant side effects (Bang et al., 2005; Lee et al., 2010), safety issues carefully need to be taken into account when considering MSCs for the treatment of ischemic stroke. MSC treatment was associated with improved outcome of stroke patients in at least some of the aforementioned studies, suggesting that MSC transplantation is safe. Likewise, a large meta-analysis on clinical trials under various pathological conditions not exclusively related to stroke did not show any evidence for severe side effects due to MSC transplantation (Lalu et al., 2012). This work analyzed safety issues in 36 studies covering a total of 1012 participants that had suffered from stroke, Crohn's disease, cardiomyopathy, myocardial infarction or graft vs. host disease. Some studies also included MSC transplantation in healthy non-affected volunteers. The meta-analysis did not detect significant side effects related to MSC transplantation, such as acute infusion-related toxicity, complications in peripheral organ systems, infection, death, or tumor formation. There was, however, a consistent observation of MSC transplantation-related transient fever.

Nevertheless, setbacks and unfavorable reports in experimental stroke models deserve special attention. Using intraarterial transplantation paradigms in a rat stroke model, Mitkari et al. could not show improved functional outcome after MSC transplantation, although grafted MSCs were attracted towards the lesion site and post-ischemic angiogenesis was significantly increased (Mitkari et al., 2014). In line with this, Steiner and colleagues did not observe post-stroke neuroprotection after systemic MSC transplantation in rodents, which was attributed to homing of grafted MSCs into peripheral organs and not into the brain (Steiner et al., 2012). Most importantly, transplantation risks might increase when comorbidities such as diabetes are taken into account. As such, Chen et al. did not show a beneficial effect of MSCs in diabetic stroke rats, but even reported increased mortality in treated animals that was associated with enhanced brain hemorrhage as a consequence of maladaptive angiogenesis (Chen et al., 2011).

Although MSCs themselves are not tumorigenic, they might migrate to existing primary tumors and modify or even stimulate tumor growth due to their immunomodulatory properties (Lazennec and Jorgensen, 2008). Accordingly, MSC-induced bystander effects might change the biological behavior of tumor cells with unpredictable consequences for the patient. Hence, further clinical trials using larger study cohorts with extended observation periods are urgently needed before more definite conclusions about the safety of MSC transplantation may be drawn. In view of risks related to invasive procedures, such studies should preferably use intravenous instead of delivery strategies from the authors' point of view.

\section{NEURAL STEM AND PROGENITOR CELLS AND OTHER STEM CELL SOURCES}

In comparison with MSCs, other cell types have been less frequently evaluated in clinical studies. The hesitation of delivering these cells to human stroke patients is a consequence of the fact that unlike MSCs, which are used for bone marrow transplantation, these cells had not been used before as therapeutics in other medical contexts. In case of NPCs, concerns remain about malignant transformation, which cannot be ruled out completely even when fetal or adult cell sources are used. NPCs derived from the SVZ of the lateral ventricles induce potent neuroprotection and brain remodeling, both when systemically and locally (i.e., intracerebrally) delivered. This aspect deserves special attention, since cells are not integrated into neural networks but act mainly via paracrine bystander mechanisms (Bacigaluppi et al., 2008, 2009; Doeppner et al., 2010, 2012). Two clinical trials have demonstrated the feasibility of stereotactic delivery of cultured neuronal cells derived from a teratocarcinoma cell line (Kondziolka et al., 2000, 2005). Although cell transplantation was followed by some functional improvement, the primary outcome measure of the study, the change in the European Stroke Scale (ESS) motor score, was not met. Again, the sample size (4-7 patients per group) was too small to infer conclusions regarding the therapeutic efficacy of NPC transplantation.

Another study using fetal porcine NPCs pre-treated with an anti-MHC class I antibody for prevention of graft rejection could not confirm its high expectations regarding safety and feasibility (Savitz et al., 2005). Noteworthy, this trial was stopped after intracerebral transplantation into five patients resulted in significant side effects in two patients. Thus, temporary worsening of motor deficits was noted in one patient 3 weeks after transplantation, while another patient developed epileptic seizures 1 week after transplantation (Savitz et al., 2005). MRI in both patients demonstrated areas of contrast enhancement remote from the grafting site, which resolved on subsequent imaging. In contrast to this study, another study investigating the intrathecal transplantation of cell suspensions derived from immature nervous and hematopoietic tissues did not detect any side effects in 10 patients over an observation period of 6 months (Rabinovich et al., 2005). Although the number of published clinical studies investigating cell sources other than MSCs is low, additional studies are on the way in stroke patients using cells from different tissue sources. Among these ones, studies using genetically modified NPCs are noteworthy, which are delivered by stereotactic intracerebral transplantation (NCT02117635 and NCT01151124). In other studies, human placenta-derived cells (NCT01310114) or olfactory ensheathing cells (NCT01327768) are applied. While the former study is already completed but not yet published, the status of the latter is currently unknown. ${ }^{2}$ Unfortunately, the aforementioned studies make use of intraparenchymal transplantation strategies, which reduces their clinical relevance, even in case they prove to be successful.

\section{CONCLUSION AND OUTLOOK}

Whereas application of stem cells has become a clinical routine for treatment of hematological diseases, neurorestaurative treatment paradigms using stem cells against stroke have not found their way into the clinic, yet. However, first proof-of-concept studies evaluating MSC transplantation in human stroke patients achieved promising data, which justify more systematic studies. These

\footnotetext{
${ }^{2}$ www.clinicaltrials.gov
} 
observations will have to be confirmed in larger cohorts in the near future, before more definite conclusions regarding the safety of stem cell treatment can be made. Unfortunately, recruitment in some of the ongoing studies was rather slow in recent years, which delays progress in the field of stem cell therapies. A major problem of several previous studies is the lack of appropriate control groups. On the other hand, clinical trials using cell sources other than MSCs are still scarce and need further evaluation. In the absence of clinical experience in larger patient cohorts, questions of long-term safety remain a concern for most of the latter cell sources, even when fetal or adult cells are used.

\section{AUTHOR AND CONTRIBUTIONS}

Thorsten R. Doeppner and Dirk M. Hermann wrote the manuscript.

\section{ACKNOWLEDGMENTS}

This work was supported by grants from the Deutsche Forschungsgemeinschaft (HE3173/2-1, HE3173/2-2, and HE3173/3-1; to Dirk M. Hermann).

\section{REFERENCES}

Aggarwal, S., and Pittenger, M. F. (2005). Human mesenchymal stem cells modulate allogeneic immune cell responses. Blood 105, 1815-1822. doi: 10.1182/blood2004-04-1559

Alvarez-Buylla, A., and Garcia-Verdugo, J. M. (2002). Neurogenesis in adult subventricular zone. J. Neurosci. 22, 629-634.

Arvidsson, A., Collin, T., Kirik, D., Kokaia, Z., and Lindvall, O. (2002). Neuronal replacement from endogenous precursors in the adult brain after stroke. Nat. Med. 8, 963-970. doi: 10.1038/nm747

Bacigaluppi, M., Pluchino, S., Martino, G., Kilic, E., and Hermann, D. M. (2008). Neural stem/precursor cells for the treatment of ischemic stroke. J. Neurol. Sci. 265, 73-77. doi: 10.1016/j.jns.2007.06.012

Bacigaluppi, M., Pluchino, S., Peruzzotti Jametti, L., Kilic, E., Kilic, U., Salani, G., et al. (2009). Delayed post-ischaemic neuroprotection following systemic neural stem cell transplantation involves multiple mechanisms. Brain 132, 2239-2251. doi: 10.1093/brain/awp174

Banerjee, S., Williamson, D. A., Habib, N., and Chataway, J. (2012). The potential benefit of stem cell therapy after stroke: an update. Vasc. Health Risk Manag. 8, 569-580. doi: 10.2147/VHRM.s25745

Bang, O. Y., Lee, J. S., Lee, P. H., and Lee, G. (2005). Autologous mesenchymal stem cell transplantation in stroke patients. Ann. Neurol. 57, 874-882. doi: 10. 1002/ana.20501

Barbosa da Fonseca, L. M., Gutfilen, B., Rosado de Castro, P. H., Battistella, V., Goldenberg, R. C., Kasai-Brunswick, T., et al. (2010). Migration and homing of bone-marrow mononuclear cells in chronic ischemic stroke after intraarterial injection. Exp. Neurol. 221, 122-128. doi: 10.1016/j.expneurol.2009. 10.010

Battistella, V., de Freitas, G. R., da Fonseca, L. M., Mercante, D., Gutfilen, B., Goldenberg, R. C., et al. (2011). Safety of autologous bone marrow mononuclear cell transplantation in patients with nonacute ischemic stroke. Regen. Med. 6, 45-52. doi: 10.2217/rme.10.97

Beyth, S., Borovsky, Z., Mevorach, D., Liebergall, M., Gazit, Z., Aslan, H., et al. (2005). Human mesenchymal stem cells alter antigen-presenting cell maturation and induce T-cell unresponsiveness. Blood 105, 2214-2219. doi: 10.1182/blood2004-07-2921

Bhasin, A., Srivastava, M. V., Kumaran, S. S., Mohanty, S., Bhatia, R., Bose, S., et al. (2011). Autologous mesenchymal stem cells in chronic stroke. Cerebrovasc. Dis. Extra 1, 93-104. doi: 10.1159/000333381

Bhasin, A., Srivastava, M. V., Mohanty, S., Bhatia, R., Kumaran, S. S., and Bose, S. (2013). Stem cell therapy: a clinical trial of stroke. Clin. Neurol. Neurosurg. 115, 1003-1008. doi: 10.1016/j.clineuro.2012.10.015

Bliss, T. M., Andres, R. H., and Steinberg, G. K. (2010). Optimizing the success of cell transplantation therapy for stroke. Neurobiol. Dis. 37, 275-283. doi: 10. 1016/j.nbd.2009.10.003
Bliss, T., Guzman, R., Daadi, M., and Steinberg, G. K. (2007). Cell transplantation therapy for stroke. Stroke 38, 817-826. doi: 10.1161/01.str.0000247888. 25985.62

Blum, B., and Benvenisty, N. (2008). The tumorigenicity of human embryonic stem cells. Adv. Cancer Res. 100, 133-158. doi: 10.1016/S0065-230X(08)00005-5

Blum, B., and Benvenisty, N. (2009). The tumorigenicity of diploid and aneuploid human pluripotent stem cells. Cell Cycle 8, 3822-3830. doi: 10.4161/cc.8.23. 10067

Braun, S. M., and Jessberger, S. (2014). Adult neurogenesis: mechanisms and functional significance. Development 141, 1983-1986. doi: 10.1242/dev.104596

Caplan, A. I. (2009). Why are MSCs therapeutic? New data: new insight. J. Pathol. 217, 318-324. doi: 10.1002/path.2469

Chen, J., Li, Y., Wang, L., Zhang, Z., Lu, D., Lu, M., et al. (2001). Therapeutic benefit of intravenous administration of bone marrow stromal cells after cerebral ischemia in rats. Stroke 32, 1005-1011. doi: 10.1161/01.str.32.4.1005

Chen, J., Ye, X., Yan, T., Zhang, C., Yang, X. P., Cui, X., et al. (2011). Adverse effects of bone marrow stromal cell treatment of stroke in diabetic rats. Stroke 42, 35513558. doi: 10.1161/STROKEAHA.111.627174

Chen, J., Zhang, Z. G., Li, Y., Wang, L., Xu, Y. X., Gautam, S. C., et al. (2003). Intravenous administration of human bone marrow stromal cells induces angiogenesis in the ischemic boundary zone after stroke in rats. Circ. Res. 92, 692-699. doi: 10.1161/01.res.0000063425.51108.8d

Delavaran, H., Sjunnesson, H., Arvidsson, A., Lindvall, O., Norrving, B., van Westen, D., et al. (2013). Proximity of brain infarcts to regions of endogenous neurogenesis and involvement of striatum in ischaemic stroke. Eur. J. Neurol. 20, 473-479. doi: 10.1111/j.1468-1331.2012.03877.x

Doeppner, T. R., Dietz, G. P., El Aanbouri, M., Gerber, J., Witte, O. W., Bähr, M., et al. (2009). TAT-Bcl-x(L) improves survival of neuronal precursor cells in the lesioned striatum after focal cerebral ischemia. Neurobiol. Dis. 34, 87-94. doi: 10. 1016/j.nbd.2008.12.013

Doeppner, T. R., El Aanbouri, M., Dietz, G. P., Weise, J., Schwarting, S., and Bähr, M. (2010). Transplantation of TAT-Bcl-xL-transduced neural precursor cells: long-term neuroprotection after stroke. Neurobiol. Dis. 40, 265-276. doi: 10. 1016/j.nbd.2010.05.033

Doeppner, T. R., Ewert, T. A., Tönges, L., Herz, J., Zechariah, A., Elali, A., et al. (2012). Transduction of neural precursor cells with TAT-heat shock protein 70 chaperone: therapeutic potential against ischemic stroke after intrastriatal and systemic transplantation. Stem Cells 30, 1297-1310. doi: 10.1002/stem.1098

Doeppner, T. R., and Hermann, D. M. (2010). Mesenchymal stem cells in the treatment of ischemic stroke: progress and possibilities. Stem Cells Cloning 3, 157-163. doi: 10.2147/SCCAA.s7820

Doetsch, F., Caillé, I., Lim, D. A., García-Verdugo, J. M., and Alvarez-Buylla, A. (1999). Subventricular zone astrocytes are neural stem cells in the adult mammalian brain. Cell 97, 703-716. doi: 10.1016/s0092-8674(00)80783-7

Doetsch, F., García-Verdugo, J. M., and Alvarez-Buylla, A. (1997). Cellular composition and three-dimensional organization of the subventricular germinal zone in the adult mammalian brain. J. Neurosci. 17, 5046-5061.

Dominici, M., Le Blanc, K., Mueller, I., Slaper-Cortenbach, I., Marini, F., Krause, D., et al. (2006). Minimal criteria for defining multipotent mesenchymal stromal cells. The international society for cellular therapy position statement. Cytotherapy 8, 315-317. doi: 10.1080/14653240600855905

Haas, S., Weidner, N., and Winkler, J. (2005). Adult stem cell therapy in stroke. Curr. Opin. Neurol. 18, 59-64. doi: 10.1097/00019052-200502000-00012

Hermann, D. M., and Chopp, M. (2012). Promoting brain remodelling and plasticity for stroke recovery: therapeutic promise and potential pitfalls of clinical translation. Lancet Neurol. 11, 369-380. doi: 10.1016/S1474-4422(12) 70039-X

Honmou, O., Houkin, K., Matsunaga, T., Niitsu, Y., Ishiai, S., Onodera, R., et al. (2011). Intravenous administration of auto serum-expanded autologous mesenchymal stem cells in stroke. Brain 134, 1790-1807. doi: 10.1093/brain/awr063

Jessberger, S., and Gage, F. H. (2014). Adult neurogenesis: bridging the gap between mice and humans. Trends Cell Biol. 24, 558-563. doi: 10.1016/j.tcb.2014.07.003

Kondziolka, D., Steinberg, G. K., Wechsler, L., Meltzer, C. C., Elder, E., Gebel, J., et al. (2005). Neurotransplantation for patients with subcortical motor stroke: a phase 2 randomized trial. J. Neurosurg. 103, 38-45. doi: 10.3171/jns.2005.103.1. 0038

Kondziolka, D., Wechsler, L., Goldstein, S., Meltzer, C., Thulborn, K. R., Gebel, J., et al. (2000). Transplantation of cultured human neuronal cells for patients with stroke. Neurology 55, 565-569. doi: 10.1212/wnl.55.4.565 
Kranz, A., Wagner, D. C., Kamprad, M., Scholz, M., Schmidt, U. R., Nitzsche, F., et al. (2010). Transplantation of placenta-derived mesenchymal stromal cells upon experimental stroke in rats. Brain Res. 1315, 128-136. doi: 10.1016/j. brainres.2009.12.001

Kurozumi, K., Nakamura, K., Tamiya, T., Kawano, Y., Ishii, K., Kobune, M., et al. (2005). Mesenchymal stem cells that produce neurotrophic factors reduce ischemic damage in the rat middle cerebral artery occlusion model. Mol. Ther. 11, 96-104. doi: 10.1016/j.ymthe.2004.09.020

Lalu, M. M., McIntyre, L., Pugliese, C., Fergusson, D., Winston, B. W., Marshall, J. C., et al. (2012). Safety of cell therapy with mesenchymal stromal cells (SafeCell): a systematic review and meta-analysis of clinical trials. PLoS One 7:e47559. doi: 10.1371/journal.pone.0047559

Lazennec, G., and Jorgensen, C. (2008). Concise review: adult multipotent stromal cells and cancer: risk or benefit? Stem cells 26, 1387-1394. doi: 10.1634/stemcells. 2007-1006

Lee, J. S., Hong, J. M., Moon, G. J., Lee, P. H., Ahn, Y. H., Bang, O. Y., et al. (2010). A long-term follow-up study of intravenous autologous mesenchymal stem cell transplantation in patients with ischemic stroke. Stem Cells 28, 10991106. doi: 10.1002/stem.430

Leong, W. K., Henshall, T. L., Arthur, A., Kremer, K. L., Lewis, M. D., Helps, S. C., et al. (2012). Human adult dental pulp stem cells enhance poststroke functional recovery through non-neural replacement mechanisms. Stem Cells Transl. Med. 1, 177-187. doi: 10.5966/sctm.2011-0039

Li, Y., Chen, J., Chen, X. G., Wang, L., Gautam, S. C., Xu, Y. X., et al. (2002). Human marrow stromal cell therapy for stroke in rat: neurotrophins and functional recovery. Neurology 59, 514-523. doi: 10.1212/wnl.59.4.514

Liu, J., Solway, K., Messing, R. O., and Sharp, F. R. (1998). Increased neurogenesis in the dentate gyrus after transient global ischemia in gerbils. J. Neurosci. 18, 7768-7778.

Mitkari, B., Nitzsche, F., Kerkelä, E., Kuptsova, K., Huttunen, J., Nystedt, J., et al. (2014). Human bone marrow mesenchymal stem/stromal cells produce efficient localization in the brain and enhanced angiogenesis after intra-arterial delivery in rats with cerebral ischemia, but this is not translated to behavioral recovery. Behav. Brain Res. 259, 50-59. doi: 10.1016/j.bbr.2013.10.030

Moniche, F., Gonzalez, A., Gonzalez-Marcos, J. R., Carmona, M., Piñero, P., Espigado, I., et al. (2012). Intra-arterial bone marrow mononuclear cells in ischemic stroke: a pilot clinical trial. Stroke 43, 2242-2244. doi: 10.1161/STROKEAHA. 112.659409

Mora-Lee, S., Sirerol-Piquer, M. S., Gutiérrez-Pérez, M., Gomez-Pinedo, U., Roobrouck, V. D., López, T., et al. (2012). Therapeutic effects of hMAPC and hMSC transplantation after stroke in mice. PLoS One 7:e43683. doi: 10.1371/journal. pone. 0043683

Onda, T., Honmou, O., Harada, K., Houkin, K., Hamada, H., and Kocsis, J. D. (2008). Therapeutic benefits by human mesenchymal stem cells (hMSCs) and Ang-1 gene-modified hMSCs after cerebral ischemia. J. Cereb. Blood Flow Metab. 28, 329-340. doi: 10.1038/sj.jcbfm.9600527

Parent, J. M. (2003). Injury-induced neurogenesis in the adult mammalian brain. Neuroscientist 9, 261-272. doi: 10.1177/1073858403252680

Pittenger, M. F., Mackay, A. M., Beck, S. C., Jaiswal, R. K., Douglas, R., Mosca, J. D., et al. (1999). Multilineage potential of adult human mesenchymal stem cells. Science 284, 143-147. doi: 10.1126/science.284.5411.143

Rabinovich, S. S., Seledtsov, V. I., Banul, N. V., Poveshchenko, O. V., Senyukov, V. V., Astrakov, S. V., et al. (2005). Cell therapy of brain stroke. Bull. Exp. Biol. Med. 139, 126-128.

Savitz, S. I., Dinsmore, J., Wu, J., Henderson, G. V., Stieg, P., and Caplan, L. R. (2005). Neurotransplantation of fetal porcine cells in patients with basal ganglia infarcts: a preliminary safety and feasibility study. Cerebrovasc. Dis. 20, 101-107. doi: $10.1159 / 000086518$

Savitz, S. I., Misra, V., Kasam, M., Juneja, H., Cox, C. S. Jr., Alderman, S., et al. (2011). Intravenous autologous bone marrow mononuclear cells for ischemic stroke. Ann. Neurol. 70, 59-69. doi: 10.1002/ana.22458

Sawada, M., Matsumoto, M., and Sawamoto, K. (2014). Vascular regulation of adult neurogenesis under physiological and pathological conditions. Front. Neurosci. 8:53. doi: $10.3389 /$ fnins.2014.00053

Schwarting, S., Litwak, S., Hao, W., Bähr, M., Weise, J., and Neumann, H. (2008). Hematopoietic stem cells reduce postischemic inflammation and ameliorate ischemic brain injury. Stroke 39, 2867-2875. doi: 10.1161/strokeaha.108.513978
Sheikh, A. M., Nagai, A., Wakabayashi, K., Narantuya, D., Kobayashi, S., Yamaguchi, S., et al. (2011). Mesenchymal stem cell transplantation modulates neuroinflammation in focal cerebral ischemia: contribution of fractalkine and IL-5. Neurobiol. Dis. 41, 717-724. doi: 10.1016/j.nbd.2010.12.009

Shen, L. H., Li, Y., Chen, J., Zacharek, A., Gao, Q., Kapke, A., et al. (2007). Therapeutic benefit of bone marrow stromal cells administered 1 month after stroke. J. Cereb. Blood Flow Metab. 27, 6-13. doi: 10.1038/sj.jcbfm.9600311

Silva-Vargas, V., Crouch, E. E., and Doetsch, F. (2013). Adult neural stem cells and their niche: a dynamic duo during homeostasis, regeneration and aging. Curr. Opin. Neurobiol. 23, 935-942. doi: 10.1016/j.conb.2013.09.004

Spees, J. L., Gregory, C. A., Singh, H., Tucker, H. A., Peister, A., Lynch, P. J., et al. (2004). Internalized antigens must be removed to prepare hypoimmunogenic mesenchymal stem cells for cell and gene therapy. Mol. Ther. 9, 747-756. doi: 10. 1016/j.ymthe.2004.02.012

Steiner, B., Roch, M., Holtkamp, N., and Kurtz, A. (2012). Systemically administered human bone marrow-derived mesenchymal stem home into peripheral organs but do not induce neuroprotective effects in the MCAo-mouse model for cerebral ischemia. Neurosci. Lett. 513, 25-30. doi: 10.1016/j.neulet.2012. 01.078

Suárez-Monteagudo, C., Hernández-Ramírez, P., Alvarez-González, L., GarcíaMaeso, I., de la Cuétara-Bernal, K., Castillo-Díaz, L., et al. (2009). Autologous bone marrow stem cell neurotransplantation in stroke patients. Restor. Neurol. Neurosci. 27, 151-161. doi: 10.3233/RNN-2009-0483

Taupin, P., and Gage, F. H. (2002). Adult neurogenesis and neural stem cells of the central nervous system in mammals. J. Neurosci. Res. 69, 745-749. doi: 10. 1002/jnr. 10378

Tonchev, A. B., Yamashima, T., Zhao, L., and Okano, H. (2003). Differential proliferative response in the postischemic hippocampus, temporal cortex and olfactory bulb of young adult macaque monkeys. Glia 42, 209-224. doi: 10. 1002/glia.10209

Ukai, R., Honmou, O., Harada, K., Houkin, K., Hamada, H., and Kocsis, J. D. (2007). Mesenchymal stem cells derived from peripheral blood protects against ischemia. J. Neurotrauma 24, 508-520. doi: 10.1089/neu.2006.0161

Yamashita, T., Ninomiya, M., Hernández Acosta, P., García-Verdugo, J. M., Sunabori, T., Sakaguchi, M., et al. (2006). Subventricular zone-derived neuroblasts migrate and differentiate into mature neurons in the post-stroke adult striatum. J. Neurosci. 26, 6627-6636. doi: 10.1523/jneurosci.0149-06.2006

Yang, B., Migliati, E., Parsha, K., Schaar, K., Xi, X., Aronowski, J., et al. (2013). Intra-arterial delivery is not superior to intravenous delivery of autologous bone marrow mononuclear cells in acute ischemic stroke. Stroke 44, 3463-3472. doi: 10.1161/strokeaha.111.000821

Yoo, S. W., Kim, S. S., Lee, S. Y., Lee, H. S., Kim, H. S., Lee, Y. D., et al. (2008). Mesenchymal stem cells promote proliferation of endogenous neural stem cells and survival of newborn cells in a rat stroke model. Exp. Mol. Med. 40, 387-397. doi: $10.3858 / \mathrm{emm} .2008 .40 .4 .387$

Zhang, J., and Chopp, M. (2013). Cell-based therapy for ischemic stroke. Expert Opin. Biol. Ther. 13, 1229-1240. doi: 10.1517/14712598.2013.804507

Zheng, W., Honmou, O., Miyata, K., Harada, K., Suzuki, J., Liu, H., et al. (2010). Therapeutic benefits of human mesenchymal stem cells derived from bone marrow after global cerebral ischemia. Brain Res. 1310, 8-16. doi: 10.1016/j. brainres.2009.11.012

Conflict of Interest Statement: The authors declare that the research was conducted in the absence of any commercial or financial relationships that could be construed as a potential conflict of interest.

Received: 16 June 2014; accepted: 12 October 2014; published online: 29 October 2014. Citation: Doeppner TR and Hermann DM (2014) Stem cell-based treatments against stroke: observations from human proof-of-concept studies and considerations regarding clinical applicability. Front. Cell. Neurosci. 8:357. doi: 10.3389/fncel.2014.00357 This article was submitted to the journal Frontiers in Cellular Neuroscience. Copyright (C) 2014 Doeppner and Hermann. This is an open-access article distributed under the terms of the Creative Commons Attribution License (CC BY). The use, distribution and reproduction in other forums is permitted, provided the original author(s) or licensor are credited and that the original publication in this journal is cited, in accordance with accepted academic practice. No use, distribution or reproduction is permitted which does not comply with these terms. 